\title{
An Investigation on Integrated Library Systems (ILS) in Use in University Libraries in Osun State, Nigeria
}

\author{
John 0. Oyekale \\ Osun State University Library, Osogbo, Nigeria \\ Email: john.oyekale@uniosun.edu.ng
}

How to cite this paper: Oyekale, J.O. (2018) An Investigation on Integrated Library Systems (ILS) in Use in University Libraries in Osun State, Nigeria. Open Access Library Journal, 5: e4915.

https://doi.org/10.4236/oalib.1104915

Received: September 17, 2018

Accepted: November 16, 2018

Published: November 19, 2018

Copyright $\odot 2018$ by author and Open Access Library Inc.

This work is licensed under the Creative Commons Attribution International License (CC BY 4.0).

http://creativecommons.org/licenses/by/4.0/

\begin{abstract}
This study investigates Integrated Library Systems (ILS) in use in university libraries in Osun State, Nigeria. It is a descriptive survey. All National Universities Commission (NUC) of Nigeria accredited universities in Osun State were selected for the study. Structured interviews (personal and telephonic) and observations were the main tools used to collect data for the study. Four (4) research questions were formulated for the study. Simple frequencies and percentages were used to analyze the data collected. The findings of the study indicated 70 of the surveyed libraries have been automated. $90 \%$ of the automated libraries adopted KOHA Integrated Library System while 10\% adopted VIRTUAL. $14.28 \%$ libraries have been fully automated while $85.71 \%$ libraries are at advance stage of automation. The study also revealed reasons for which libraries adopted a particular integrated library system to include: comprehensive functionality; library standards compliant; popularity among libraries in Nigeria; technical feasibility and support; web-based interfaces; freedom to change support company or its vendor; being an open source, and upgradability. It recommends that libraries should cooperate together to share resources and experiences to overcome libraries' financial and skills limitations.
\end{abstract}

\section{Subject Areas}

Library, Intelligence and Philology

\section{Keywords}

Integrated Library Systems, Library Management Systems, University Libraries, Osun State, Nigeria 


\section{Introduction}

In libraries, Information and Communication Technology (ICT) has become crucial in the support, sustainability, relevance and growth of the services. Libraries and librarians all over the world now depend heavily on Information and Communication Technology (ICT) to carry out their operations and render services to teaming clienteles. Automation is an important application of ICT in libraries. It facilitates fast library operations, services, and access to and delivery of information. One major ICT product heavily used in libraries to manage different library routines and processes is Integrated Library Systems (ILS) also known as Library Management Systems. The implementation of ILS to library operations and functions is no longer optional; it is a necessity. Automation in academic libraries is a big deal today. It has become a defining factor in delineating libraries. It tells how relevant, how good and how modern a library is. Of course, just like other technologies, it comes with a price-it is characterized by many challenges. But the benefits are enormous and outweighed its challenges. One major way by which libraries take advantage of Information and Telecommunication technology to facilitate unrestricted access to relevant information and to serve their users optimally is deployment of ILS. As libraries evolve their ways of working to drive innovation and serve their patrons better, a reliance on technology to automate their functions and services makes sense. Since last two decades, academic libraries in Nigeria have woken up to this reality and have embraced the use of technology to get their works done.

Integrated Library Systems are software for libraries that combine modules for cataloguing, acquisition, circulation, end-user searching, database access, and other library functions through a common set of interfaces and databases [1]. ILS are categorised into proprietary and open source integrated library systems. Proprietary ILS are commercial and protected by copyright and have strict restrictions on use and distribution. Open source ILS are free. This benefit of Open Source ILS reduces costs, gives users more control and increases software performance [2]. [3] considers software to be the most important component of the automation process in libraries.

\subsection{About Osun State}

Osun State is an inland state in South-Western Nigeria. Its capital is Osogbo. It has an area of $9251 \mathrm{~km}^{2}$ and a population of 3,423,535 according to the $2006 \mathrm{Na}$ tional Population Census [4]. According to [5], there are ten (10) accredited universities in Osun State, namely Adeleke University, Ede; Bowen University, Iwo; Fountain University, Osogbo; Joseph Ayo Babalola University, Ikeji-Arakeji; Kings University, Ode-Omu; Ladoke Akintola University of Technology Teaching Hospital, Osogbo; Obafemi Awolowo University, Ile-Ife; Oduduwa University, Ipetumodu, Ile-Ife; Osun State University, Osogbo; Redeemer's University, Ede. All the universities have libraries. 


\subsection{About University Libraries in Osun State}

Adeleke University is a private faith-based learning institution located in a serene and nature friendly atmosphere of 520 acres of land in the historic town of Ede, Osun State, South-Western part of Nigeria. The University was founded in 2011 by Dr. Adedeji Adeleke, through the Springtime Development Foundation (SDF), a philanthropic, non-profit making organisation established to assist indigent students to benefit from quality higher education [6].

Bowen University is a private Nigerian university owned and operated by the Nigerian Baptist Convention. Bowen University is located at Iwo in Osun State, Nigeria, and is housed in the old 1300-acre $\left(6 \mathrm{~km}^{2}\right)$ campus of the Baptist College, a former teacher-training institution on a hill just outside the city [7].

Fountain University is owned by Nasrul-Lahi-Il-Fatih Society (NASFAT); a leading Islamic Society in Nigeria. The University commenced operation in January 2008. Fountain University is in Oke Osun after the Osun Osogbo sacred grove in Osogbo, Nigeria. It was established by the Nasrul-lahi-li fathi (NASFAT) Society of Nigeria in 2008. It is a privately owned Islamic faith-based university in Osun State [8].

The Joseph Ayo Babalola University (JABU) is a private Nigerian university located in Ikeji-Arakeji in Osun State, established by the Christ Apostolic Church (CAC) Worldwide [9].

Kings University $(\mathrm{KU})$ is a mission and private university established by King's Ministries Trust a.k.a Kingsway International Christian Centre which is a Protestant evangelical Ministry. Kings University is situated in Ode-Omu, Osun State [10].

Ladoke Akintola University of Technology (LAUTECH) is a tertiary institution located in Ogbomosho, Oyo State, Nigeria. The University is jointly owned by Oyo and Osun states. The University has two campuses, one in Ogbomosho and the other in Osogbo [11].

Obafemi Awolowo University (OAU) was founded in 1962 as the University of Ife but rechristened by the Federal Military Government as the Obafemi Awolowo University on May 12, 1987, in honour of one of its most distinguished founding fathers and eminent nationalist, politician, lawyer, statesman and former chancellor, Chief Jeremiah Obafemi Awolowo [12].

Oduduwa University was established in 2009 and is a private University. It was located in Ipetumodu, Ile-Ife, Osun State, Nigeria. The University was named after the progenitor of the Yoruba race [5].

Osun State University is set up as a conventional and multi-campus university by Osun State Government in 2007. It has six campuses located in six geographical zones of the state. These are: Osogbo Main Campus-College of Health Sciences; College of Science, Engineering and Technology; Okuku Campus-College of Management and Social Sciences; Ikire Campus-College of Humanities and culture; Ejigbo Campus-College of Agriculture; Centre for Pre-degree Studies (Science); Ifetedo Campus-College of Law; Centre for En- 
trepreneurial Studies; Centre for Pre-Degree (Science); and Ipetu-Ijesa Campus-College of Education [13].

Redeemer's University is a private university in Ede, off Gbongan-Oshogbo Road, Osun State, Nigeria. Established in 2005, the University is owned by the Redeemed Christian Church of God [5].

\section{Statement of the Problem}

The use of Integrated Library System (ILS) in libraries across the world has helped in service delivery encouraging most libraries to adopt it. Implementation of ILS to library operations and functions is no longer optional, it is a necessity. Automation in academic libraries is a big deal today. It has become a defining factor in delineating libraries. It tells how relevant, how good and how modern a library is. This study therefore sought to investigates which libraries have automated their operations and which Integrated Library Systems (ILS) they are using.

\section{Objectives of the Study}

The main objective of this study is to investigate the Integrated Library Systems (ILS) in use in university libraries in Osun States, Nigeria.

The specific objectives of the study are to:

1) Find out which university libraries have automated there operations in Osun States Nigerian;

2) Find out the Integrated Library Systems in use in individual libraries that have automated their operations in Osun States Nigerian;

3) To identify factors that influenced the choice of Integrated Library Systems by university libraries in Osun States, Nigeria;

4) To identify what challenges the university libraries encountered in using the Integrated Library Systems of their choice.

\section{Research Questions}

In order to achieve the objectives of the study stated above, attempt was be made to find answers to the following questions:

1) Which university libraries have automated their operations in Osun State?

2) Which Integrated Library Systems are being used in university libraries in Osun State?

3) Which criteria influenced the choice of Integrated Library Systems by university libraries in Osun State?

4) What challenges were encountered by the university libraries in using Integrated Library Systems?

\section{Significance of the Study}

The study investigates the Integrated Library Systems (ILS) in use in university libraries in Osun States, Nigeria. It will lead to better understanding of current 
landscape of university libraries in Osun State with regard to adoption of Integrated Library Systems. The finding of the study will engender collaboration among libraries that are using the same type of Integrated Library Systems.

\section{Literature Review}

[14] defines Library Integrated Systems (ILS) as software designed to manage different library routines and processes. According to Wikipedia, they are enterprise resource planning systems for libraries, used to track items owned, orders made, bills paid, and patrons who have borrowed. They comprise a database, software to interact with that database, and two graphical user interfaces-one for patrons, one for staff. Generally, ILS separate software functions into discrete programs called modules, each of them integrated with a unified interface. The modules include: acquisitions, cataloguing, circulation, serials, and the OPAC. [15] defines an integrated library system (ILS) as an automated system used to manage library holdings, store patron information and track circulation transactions. [16] defines ILS as an enterprise resource planning system for a library used to track items owned, orders made, bills paid, and patrons who have borrowed. [1] defines ILS as the automation system for libraries that combines modules for Cataloguing, acquisition, circulation, end-user searching, database access, and other library functions through a common set of interfaces and databases.

From the above definitions, ILS can be said to be computer software used in libraries to perform their routine operations. They provide libraries with a variety of integrated computerized functions-Cataloguing, Circulation, Online Public Access Catalogue (OPAC), Acquisitions, and Serials control.

[17] and [18] listed ILS to include: TINLIB, GLAS, X-LIB, VIRTUA, ALICE for Windows, VIRTUA, KOHA, X-LIB, SLAM, DSpace, VTLS, GLAS, E-Lib, CD-ISIS, Atriuum, OPALS, LIBERO, LIBSYS, All My Books, Lucidea, Accessit Library, Handy Library Manager, Insignia Library System, MODERNLIB, Auto Librarian, Genesis G4, Soutron, Readerware, LIBRARIAN, Aleph, Aura Online, Autolyb, Bibliotheca, Deeksha, Easylib, Evergreen ILS, FIRST LMS, FlashScan-MAX KLAS, Lexwin, Lib-Portal, LibAnswers, Liberty, LibGuru, LIBMAN, Library Solution, Library Vision Library.Solution, LibraryPro, LiBRARYSOFT, LIBSOFT, M2L, MindLibrary, OpenText Library Management, Reademption Library EcoSystem, ROVAN LMS, Schookee, and SLIM21.

[19] posited that ILS have advantages of enabling faster processing of information and provision of easier access to relevant information. He opines that an integrated library system is superior to one which is not integrated. According to him, duplication of effort to create and maintain multiple copies of bibliographic records is eliminated in an integrated system, possibilities of errors are reduced when records are entered only once, and changes are automatically effected throughout the system.

[20] opines that the use of ILS in academic library operation is critical. That adoption and use of ILS positively affect the library and its users and that 
Non-adoption of ILS academic libraries will cause setback to delivery of quality library services to patrons. [2] posits that ILS has potential to reduce costs of running the library. [21] stated that ILS supports the general operations of the library like acquisition, cataloguing, and circulation. That ILS gives detailed information about users, staff and information resources; tracks how many resources are available in library and books charged to users; shows resources that are mostly used; keeps records; and reports for management.

Technological Factors are now being identified as an important construct in information system adoption studies in librarianship. [19] posited that in choosing ILS, libraries must base their decision performance and efficiency of the system, flexibility and adaptability to the future demands and needs of their patrons. [22] was of the opinion that library staff attitude toward the use and implementation of ICT, knowledge of ICT and training will influence adoption of ICT positively.

[23] proposed adoption guidelines for integrated library management. According to him, the following factors have direct effects on success or otherwise of ILS deployed by libraries, namely Technological factors, Library factors, Librarians' factors, Behavioural intention to Adopt ILS, Adoption of ILS System quality, Output quality, After sale service quality, Top management support, and Users training.

[24] [25] [26] [27] and [28] listed factors militating against the library's automation project to include lack of technical knowhow and systems concept; high expenses; lack of workers education; outdated software; discouragement from higher authorities; insufficient power supply, poor funding, poor administrative support and inadequate staff training.

\section{Research Methodology}

This study employed a descriptive survey method. All National Universities Commission (NUC) accredited universities in Osun State were reviewed and data were obtained from ten (10) of them.

Structured interviews (personal and telephonic) and observations were the main tools used to collect data for the study. Four (4) main questions were asked from all the representative of the ten (10) university libraries chosen for the study $(\mathrm{n}=10)$. The questions are:

1) Have you deployed Integrated Library System in your library? (If yes) Which stage are you? Is it at initial or Advance or full stage?

2) (If yes to question 1), which Integrated Library System did you install in your library?

3) Why did you adopt the Integrated Library System? Is it for its: popularity among libraries in Nigeria/free accessibility/technical feasibility and support/ constant upgrade/no maintenance fee/no software license fee/performance of all the functions needed in my library?

4) What challenges have you encountered in using the Integrated Library Sys- 
tem you have chosen?

\section{Data Analysis and Results}

Data collected were analysed using frequency distribution table and percentages.

\section{The selected university libraries}

Table 1 shows the list of the selected university libraries. 1 (10\%) of the selected universities is owned by the Federal Government of Nigeria, 2 (20\%) of them are owned by State Governments while 7 (70\%) are owned by private individuals and religious organizations.

Which Integrated Library Systems are installed in libraries?

Table 2 shows the analysis of responses to Research Questions 1 and 2. It Table 1. Selected university libraries.

\begin{tabular}{|c|c|c|c|c|}
\hline Sn & Universities & Location & Founder & Founded \\
\hline 1 & Adeleke University (AU) & Ede & Private & 2011 \\
\hline 2 & Bowen University (BU) & Iwo & Private & 2002 \\
\hline 3 & Fountain University, Osogbo (FUO) & Osogbo & Private & 2007 \\
\hline 4 & Joseph Ayo Babalola University (JABU) & Ikeji-Arakeji & Private & 2006 \\
\hline 5 & King's University (KU) & Ode-Omu & Private & 2009 \\
\hline 6 & $\begin{array}{c}\text { Ladoke Akintola University of Technology } \\
\text { Teaching Hospital (LAUTECTH) }\end{array}$ & Osogbo & State Government & 1991 \\
\hline 7 & Obafemi Awolowo University (OAU) & Ile Ife & Federal Government & 1962 \\
\hline 8 & Oduduwa University (OUI) & Ipetumodu & Private & 2009 \\
\hline 9 & Osun State University (UNIOSUN) & Osogbo & State Government & 2007 \\
\hline 10 & Redeemer's University (RUN) & Ede & Private & 2005 \\
\hline
\end{tabular}

Source: National Universities Commission of Nigeria Website-www.nuc.edu.ng.

Table 2. Deployment of Integrated Library Systems $(\mathrm{N}=10)$.

\begin{tabular}{ccccc}
\hline Sn & Libraries & $\begin{array}{c}\text { Deployment } \\
\text { of ILS }\end{array}$ & ILS in use & $\begin{array}{c}\text { Extent of } \\
\text { Deployment }\end{array}$ \\
\hline 1 & Adeleke University Library & Yes & KOHA & Advance \\
2 & Bowen University Library & Yes & KOHA & FULL \\
3 & Fountain University Library & No & - & Planning to deploy ILS \\
4 & Joseph Ayo Babalola University Library & Yes & KOHA & Advance \\
5 & King's University Library & No & - & Planning to deploy ILS \\
6 & $\begin{array}{c}\text { Ladoke Akintola University of } \\
\text { Technology Teaching Hospital Library }\end{array}$ & Yes & KOHA & Advance \\
7 & Obafemi Awolowo University Library & Yes & VIRTUAL & Advance \\
8 & Oduduwa University Library & No & - & Planning to deploy ILS \\
9 & Osun State University Library & Yes & KOHA & Advance \\
10 & Redeemer's University Library & Yes & KOHA & Advance \\
\hline
\end{tabular}


revealed libraries which have installed ILS and extent of deployment of ILS.

From Table 2, 7 (70\%) of the surveyed libraries have been automated while $3(30 \%)$ have not. $6(90 \%)$ of the automated libraries adopted KOHA Integrated Library System while 1 (10\%) adopted VIRTUAL Integrated Library System.

Table 2 also revealed that only 1 (14.28\%) library has been fully automated while $6(85.71 \%)$ libraries were at Advance stage of automation.

Further information provided by respondents revealed that three libraries that were not automated were also considering adopting an open source Integrated Library System (KOHA) with cost and efficiency being the main consideration.

Why did libraries adopt the Integrated Library System they are using?

Table 3 revealed reasons for which the libraries surveyed adopted their Integrated Library Systems.

All the 7 (100\%) libraries that have implemented Integrated Library System indicated that they adopted their Integrated Library System because:

1) it is customizable to meet a library's unique needs

2) of its lower financial obligation-acquisition cost and annual license fees

3) it is Library Standards compliant

4) it has comprehensive functionality

5) of its technical feasibility and support

6) constant upgradability

What challenges have libraries encountered in using the Integrated Library Systems?

Table 4 shows the challenges encountered by the libraries surveyed in using Integrated Library Systems.

From Table 4, all the respondents indicated Lack of constant power supply, high cost of training, inadequate management support for the project, minimum involvement of academic institutions in Network building and diffusion in $\mathrm{Ni}$ geria, undeveloped Information infrastructure in Nigeria, shortage of trainers, poor awareness of training opportunity, and poor ICT facilities in the academic community as problem they had encountered in using Integrated Library

Table 3. Reasons for adopting specific integrated library systems $(n=7)$.

\begin{tabular}{cccc}
\hline Sn & Reasons & Freq & $\%$ \\
\hline 1 & Customizable to meet a library's unique needs & 7 & 100 \\
2 & Lower financial obligation-acquisition cost and annual licence & 7 & 100 \\
3 & Library Standards Compliant & 7 & 100 \\
4 & Comprehensive functionality & 7 & 100 \\
5 & Popularity among libraries in Nigeria & 6 & 85.71 \\
6 & Technical feasibility and support & 7 & 100 \\
7 & Constant upgradability & 7 & 100 \\
8 & Web-based Interfaces & 6 & 85.71 \\
\hline
\end{tabular}


Table 4. Challenges encountered in using integrated library systems $(n=7)$.

\begin{tabular}{cccc}
\hline Sn & Challenges & Freq & $\%$ \\
\hline 1 & Lack of constant power supply & 7 & 100 \\
2 & High cost of training & 7 & 100 \\
3 & Inadequate management support for the project & 7 & 100 \\
4 & Need for in-house staff expertise to customize the ILS & 7 & 100 \\
5 & Undeveloped Information infrastructure in Nigeria & 7 & 100 \\
6 & Lack of adequate technical support & 7 & 100 \\
7 & Poor awareness of training opportunity in academic community & 7 & 100 \\
8 & Poor IT facilities in the academic community & 7 & 100 \\
\hline
\end{tabular}

Systems.

\section{Discussion of Findings}

The study revealed that there are ten (10) university libraries in Osun State, Nigeria. Three (3) of ten universities are public and seven are privately owned. This showed there is proliferation of university in the State. The findings of the study also showed that most of the libraries have automated their operations. This supports earlier studies by [24] and [29] who found that academic libraries in the universities were making effort to engage in automation. Managements of university libraries have realised that automation is no longer an option but necessity. $90 \%$ of the automated libraries adopted KOHA Integrated Library System. This also supported the claim of [30] that there has been a huge interest in Koha in Nigerian libraries in the last one decade. That dozens of libraries are currently running Koha with several more in the process of migrating to Koha soon. It also supported earlier study of [31] who found that KOHA ILS was the most commonly adopted software in academic libraries in South-Western Nigeria. It was discovered during the course of the survey that Projektlink Konsult Limited Installed KOHA in most of libraries in Osun State. It was Projektlink Konsult Limited that is promoting the use of Koha and other open source software in Osun State Institutions. The Firm popularised and made Koha more visible through visitations to libraries, workshops, conferences, training, and other installation services. Most of the academic libraries are using the same type of ILS-KOHA in the State. The reason being that as libraries consult with one another in attempt to automate their functions they discovered that a library is using KOHA and that it works, it is efficient, customizable to meet their library's unique needs, it is Library Standards compliant, it has comprehensive functionality, and that it is upgradable; they therefore adopt it for their libraries too. This is a good thing and it should engender cooperation among the libraries in the State. Most of the challenges the libraries said they were experiencing in operating ILS were the same old problems of infrastructure deficit in Nigeria. It means government is not seeing to infrastructural development in the Country 
as it should.

\section{Conclusion}

There has been a huge interest and obvious utilization of ILS in university libraries in Osun State, Nigeria. Most of libraries are currently running KOHA ILS with other more in the process of adopting or migrating to KOHA ILS. The old problems of critical infrastructural deficit-lack of constant power supply, poor ICT facilities, and poor Internet connectivity are still bedevilling ICT deployment in libraries in the State; this ought not to be. Other challenges include high cost of training, inadequate management support for the project and shortage of trainers.

\section{Recommendations}

This study recommends that:

1) University libraries in Osun State should create forum for sharing resources and experiences.

2) Governments and proprietors of libraries should make funding of library a top priority.

3) Libraries should make training and retraining of their staff on ILS a top priority.

4) Government and university management should ensure constant power supply in all university libraries.

5) Governments, proprietors and university management should ensure high band Internet connectivity in libraries.

\section{Conflicts of Interest}

The author declares no conflicts of interest regarding the publication of this paper.

\section{References}

[1] Idea Group Inc. (n.d.) What Is Integrated Library System? https://www.igi-global.com/dictionary/integrated-library-system/14930

[2] Kumar, V. and Abraham, T. (nd) Eight Things You Should Know about Open Source Integrated Library Systems. http://eprints.rclis.org/13858/1/20.pdf

[3] Malik, K.M. (1996) Status of Library Automation in Pakistan. Library Review, 45, 36-42. https://doi.org/10.1108/00242539610125668

[4] Osun State Government Website. http://osun.gov.ng/

[5] National Universities Commission (NUC) of Nigeria Website. http://nuc.edu.ng

[6] Adeleke University Website. http://www.adelekeuniversity.edu.ng

[7] Bowen University Website. http://www.bowenuniversity-edu.org

[8] Fountain University Website. http://www.fountainuniversity.edu.ng

[9] Joseph Ayo Babalola University Website. http://www.jabu.edu.ng

[10] Kings University Website. http://www.kingsuniversity.edu.ng/ 
[11] LAUTECH Website. http://www.lautech.edu.ng

[12] Obafemi Awolowo University Website. http://www.oauife.edu.ng

[13] Osun State University Website. http://www.uniosun.edu.ng

[14] Wikipedia (nd) Osun State. https://en.wikipedia.org/wiki/Osun_State

[15] Keystone Systems, Inc. (2018) What Is an ILS? http://www.klas.com/general/what-is-an-ils

[16] New World Encyclopedia (2018) Integrated Library System. http://www.newworldencyclopedia.org/entry/Integrated_library_system

[17] Capterra (n.d.) Library Automation Software. https://www.capterra.com/library-automation-software/?utf8=\%E2\%9C\%93\&users =\&sort_options=Highest + Rated

[18] Obajemu, A.S., Osagie, J.N., Akinade, H.O.J. and Ekere, F.C. (2013) Library Software Products in Nigeria: A Survey of Uses and Assessment. International Journal of Library and Information Science, 5, 113-125. https://academicjournals.org/article/article1379697220_Obajemu\%20et\%20al.pdf

[19] Ashikuzzaman, M. (2014) Integrated Library Systems. http://www.lisbdnet.com/advantages-of-integrated-library-syste/

[20] Omeluzor, S.U. and Oyovwe-Tinuoye, G.O. (2016) Assessing the Adoption and Use of Integrated Library Systems (ILS) for Library Service Provision in Academic Libraries in Edo and Delta States, Nigeria. Library Review, 65, 578-592. https://doi.org/10.1108/LR-01-2016-0005

[21] Wordpress (2012) Library Management System. https://dsakernel12.wordpress.com/tag/introduction-of-library-management-system/

[22] Eguavoen, O.E.L. (2011) Attitudes of Library Staff to the Use of ICT: The Case of Kenneth Dike Library, University of Ibadan, Nigeria. Ozean Journal of Social Sciences, 4, 1-9. https://pdfs.semanticscholar.org/78ff/c2f5d819aded6e35d99ca2e3115b20f82035.pdf

[23] Adegbore, A. (2016) Adoption Guideline for Integrated Library Management Systems in Nigerian Libraries-A Theoretical Approach.

https://www.slideshare.net/adebayoadegbore/adoption-guideline-for-integrated-libr ary-management-systems-in-nigerian-libraries-a-theoretical-approach

[24] Gbadamosi, B.O. (2012) Emerging Challenges to Effective Library Automation and an E-Library: The Case of Emmanuel Alayande College of Education, Oyo, Nigeria. Library Philosophy and Practice, 1-11. http://digitalcommons.unl.edu/libphilprac/807

[25] Emezie, N.A. and Nwaohiri, N.M. (2014) The Challenges of Library Automation in Nigerian Universities of Technology: The Example of Federal University of Technology, Owerri, Nigeria. The Information Technologist, 11, 188. https://www.ajol.info/index.php/ict/article/view/109506

[26] Mishra, A., Thakur, S. and Singh, T. (2015) Library Automation: Issues, Challenges and Remedies.

https://www.researchgate.net/publication/277668181_LIBRARY_AUTOMATION_ ISSUES_CHALLENGES_AND_REMEDIES_AUTHOR/citations

[27] Das, M. (2016) Issues and Challenges of Library Automation in the College Library of Assam with Special Reference to Kamrup District-A Study. http://ir.inflibnet.ac.in:8080/ir/bitstream/1944/2026/1/22.pdf

[28] Athanasius, J. (2018) Problems and Prospects of Library Automation in Nigeria. https://infoguidenigeria.com/problems-prospects-library-automation-nigeria/ 
[29] Otunla, A.O. (2016) Current Status of Automation in Academic Libraries in Osun State Nigeria. Journal of Applied Information Science, 9, 30-39.

[30] Projektlink Konsult Limited (n.d.) Kohacon15 Bid Website. http://kohacon15bid.projektlinkkonsult.com/

[31] Iroaganachi, M.A., Iwu, J.J. and Esse, U.C. (2015) Software Selection and Deployment for Library Cooperation and Resource Sharing among Academic Libraries in South-West Nigeria. Desidoc Journal of Library and Information Technology, 35, 3-8. https://doi.org/10.14429/djlit.35.1.6885 